\title{
EXPLORING THE IMPACT OF MATRIMONIAL LITIGATION ON MEN'S HEALTH
}

\section{B. G. Ponnappa ${ }^{1}$}

${ }^{1}$ Assistant Professor, Department of Surgery, Adichunchanagiri Institute of Medical Sciences.

ABSTRACT
BACKGROUND
A true improvement in men's health can be brought about by not just the medical fraternity but also involves changes in the socio-
political environment. An effort is made to study the various matrimonial issues impacting on men's health. This preliminary
report reveals a range of ailments which are unwittingly dumped on men by the existing societal policies and also due to the lack of
policies which have a positive impact on the health of men. This paper is intended to stimulate further thoughts and studies in a
new perspective.

\section{KEYWORDS}

Men's Health, Men's Issues, Matrimonial Litigation.

HOW TO CITE THIS ARTICLE: Ponnappa BG. Exploring the impact of matrimonial litigation on men's health. J. Evolution Med. Dent. Sci. 2017;6(21):1742-1744, DOI: 10.14260/Jemds/2017/383

\section{BACKGROUND}

Though professionally a Surgeon, I was involved with a group for about eight years now, which counsels men caught up in marital conflict and litigation. During this time, I was exposed not only to the surgical problems of men but also a different set of problems of more than 1500 men, which had an impact on their health which is not addressed by the society. So I started a Men's clinic in 2013, where an attempt was made with a holistic approach to the problems faced by men. Hereunder, I present the findings obtained from the data collected over about two years and have done a literature review of the same.

\section{MATERIALS AND METHODS}

Samples of this study comprise of men who had marital issues and litigation who attended the Men's clinic. A total of 287 people visited the clinic which was run on weekends mostly by prior appointments. Of the 221 male patients, 167 $(75.56 \%)$ were for surgical problems and the remaining 54 (24.42) were for matrimony related problems. Though the clinic was intended for men, I saw 66 (1: 3.34, F: M ratio) women patients also because they were either treated by me earlier or due to ignorance of the fact that it was meant for men only. The data were collected from consultation notes made during the unstructured interview.

\section{RESULTS}

This is a preliminary report of an ongoing socioepidemiological study. As the initial data collected was not obtained with the purpose of a study it is not structured and at this point of time does not have any statistical analysis of the data. About 54 men with matrimony related problems were interviewed and notes made. I will not be able to give definitive numbers for each of the issues because each individual presented with multiple allegations and because

Financial or Other, Competing Interest: None.

Submission 03-01-2017, Peer Review 27-02-2017,

Acceptance 04-03-2017, Published 13-03-2017.

Corresponding Author:

Dr. B. G. Ponnappa,

\#139, $7^{\text {th }}$ Main, Gokulam $3^{\text {rd }}$ Stage,

Mysore 570002.

E-mail: bgponnappa@gmail.com

DOI: $10.14260 /$ jemds $/ 2017 / 383$

\section{(c) $(1) \ominus$}

this data collection was not structured to begin with. The common health complaint encountered is given in Table. 1.

\section{Men's Health issues due to Matrimonial Litigation} Stress, Depression, Anxiety, Sexual problems, Sleeplessness, Alcoholism, Smoking, Suicidal thoughts, Overworking, Oversleeping, Anger, Obesity Table 1

Marital conflict which usually ended with multiple court cases dragged on for years together, many of them reportedly false, and all arising out of one event called 'marriage'. The common cases filed are given in Table. 2

\section{Types of Cases Filed}

Dowry, Harassment case, Marital rape, Attempted murder, Abetting suicide attempts, Maintenance case U/S 125 CrPC,

Domestic violence case, Divorce Restitution of conjugal rights, Child custody case, Child abuse cases related appeals

\section{Table 2}

The common hardships faced are listed in Table. 3.

Hardship Faced due to Matrimonial Litigation

Financial hardship due to alimony, maintenance, bail and other litigation costs. Miscellaneous expenditures due to travel, food, stay. Loss of potential income, Job loss, Frequent travel from far of places to attend the case only to be adjourned. Social isolation Facing police procedures - both

formal and undocumented unconventional methods.

Detention and judicial custody purely on the basis of an allegation. Stigma of being jailed. Separation from children and frustration. Implicating elderly parents and unmarried siblings. Table 3

\section{DISCUSSION AND LITERATURE REVIEW}

"There is a long established male disadvantage in health."(1) The social expectations and demands of the society from men creates a situation which affects their health. The problem in this study is all due to the matrimonial litigation which caused the various health related problems.

The physical, psychological and social health depends on the sex of the individual also. Research in both clinical and community medicine will be effective only if these differences between the sexes are acknowledged.(2) 
We know that the WHO defines health as a "state of complete physical, mental and social wellbeing and not merely an absence of disease or infirmity and also includes the ability to lead a socially and economically productive life". Whereas, Men's health issues are issues that affect the quality of life of men and for which different remedial measures are needed to experience optimal health.(3)

The men in this study had considerable matrimony related mental health issues but had nowhere to go. All the matrimonial laws are designed understandably to protect women and their rights. But the same laws, become a men's health issue, when they are misused and abused by the society. Talking about the misuse of dowry provisions of IPC, the Supreme Court of India said that many cases of dowry are filed with mala fide intensions and oblique motives whereby "legal terrorism" is unleashed to humiliate the accused men.(4)

A divorce case filed in a court is always accompanied with a package of accessory cases being filed as mentioned earlier. This induces a lot of unnecessary stress. Divorced men have higher rates of mortality, substance abuse, depression, and lack of social support.(5) Many reported that there is no help for men facing domestic violence from their female partner as there is no law to protect them. If they sought to complain it to the police, they were ridiculed and sent back or much worse harassed by a counter complaint, and the male victim is arrested instead of the female perpetrator. Male victims of domestic violence were more likely to be arrested upon calling the police than the female perpetrator.(6) There are many factors for the increase in violence against men by women.

Men are portrayed as being "Macho" and not vulnerable to psychological trauma by the media and the society, which is unfounded and research is needed in this aspect for knowing its impact and developing guidelines for diagnosis and treatment."(7) It is well known that men are reluctant to seek support for their ailment. (8)

In India the society seems to be forcing the traditional prejudicial view of man to be the 'Protector and Provider'. The Supreme Court of India in criminal appeal No.1331 of 2014 has said "it is the sacrosanct duty to render the financial support (to wife) even if the husband is required to earn money with physical labour, if he is able bodied".(9) This is obviously reinforcing the patriarchal norm as the woman is made to be dependent on a man for her sustenance but no one seems to object to this outdated concept in the present era of equality. Men are motivated to support hegemonic masculinity.(10) The Indian marital laws seems to be reinforcing hegemonic masculinity not by motivation but by compulsion.

There are various programs designed for women starting from maternal health to allocating funds in national budget for their safety but none whatsoever for men. Men are exposed to risky jobs and behaviours, accidents, violent crimes and suicide is more in men, and more laws are framed to the disadvantage of men leading to physical, psychological, financial and social misery. In spite of the fundamental right to equality between sex (and genders), men are still the expendable sex. The problems of smoking needs to be addressed as it leads not only to thromboangiitis obliterans and various cancers but also to pneumonia, cough and chronic obstructive airway disease. Excessive alcohol consumption leads to trauma, violence, organ system damage, various cancers, leads to unsafe sexual practices, premature death and poor nutritional status. There is an overwhelming male preponderance (30\% male, $4 \%$ female) among injuries resulting from one's own drinking alcohol. The overall male: female ratio of suicide victims for the year 2014 was 67.7:32.3. The life expectancy of Indian males is 63.8 which is less than that of a female which is 67.3 and a lot of causes are being listed out.

Men are also troubled by poor nutrition, physical inactivity, being overweight or obese and being diabetic and hypertensive. But there are no schemes or projects to study the welfare of men and there are no funds allocated. Low serum testosterone levels in men have been associated with irritable male syndrome, an increased risk of diabetes mellitus, obesity, metabolic syndrome, osteoporosis, cardiovascular events, and all-cause mortality and we do not have any screening programs. Depression, antisocial behaviour, drug issues, erectile dysfunction and premature ejaculation also needs to be addressed with a regular counselling and appropriate treatment by specialists. Certain programs like hearing and vision screening, depression screening, bone health evaluation, testicular cancer screening, prostate cancer, hyperplasia, prostatitis screening, sexual health \& safe sexual practice advisory needs to be organised formally. In some countries, there are exclusive men's clinics and similar clinics have to be set up in India too. Society forces men to compete and dominate which incites violence and breeds contempt. This is responsible for a lot of psychological issues which men are reluctant to acknowledge and seek medical help.(11) Instead of "Blaming men" and try to "Re-educate" them, the health services should be able to better meet the needs of men. Not many researchers identify male sex and masculinity as a risk factor that threatens men's health.(12)

Men's health is basically a neglected topic in India. The men who visited the clinic for relationship problems, which caused an impediment to their health, could have been better off, if there was gender neutral laws and a forum to hear and help them face the situation rather than seeing them as a perpetrator of crime and swindling them of their finances. Time may be ripe to have a 'Department for Men's Welfare' and a separate 'Ministry for Men'. Probably 'The Indian Medical Association' and other medical bodies should become more proactive and study men's health with regards to the social determinants of health and come out with a policy recommendations to the appropriate authorities. Gender equity is the process of being fair to women and men.(13) We need to realise that the word 'gender justice' and 'gender equality' must be construed in a neutral tone which it implies, and not just ascribe it to the betterment of women only, which is at present, the norm. Our health depends a lot on opportunities, resources, social interactions and quality of our relationships at home and with the community. It is tough to imagine improvements in all the above sectors overnight, but a beginning has to be made with emphasis on men's health also.

\section{ACKNOWLEDGEMENTS}

I thank all the people who participated in organising the Men's Health Clinic at Mysore and all the people who visited and shared their problems and views with the author. I also 
thank the members of PURE, Mysore for their contribution in this study.

\section{CONCLUSION}

The society which is striving to empower women and uphold the constitutionally guaranteed equality seems to be undercutting the basic human rights of the Indian male when it comes to his overall health. While women's role change is welcome and encouraged, men's role seems to be stuck in the web of hypocrisy. It is argued that men earn more, but they also pay more tax and the investment on men's health if any is negligible. The society for various reasons 'was and is' obsessed with women and children and 'Misandry' is obvious. This article is intended basically to kindle interest in policy makers, health researchers, social scientists to look into men's health in India in a contemporaneous setting without prejudice with a view to improve men's health in the years to come. As John J Macdonald argues - we need to adopt the well-known 'Social Determinants of Health' perspective to assist in evidence based development of men's health policies and practice. $(14)$

\section{REFERENCES}

[1] Watson J. Male bodies: health, culture and identity. Buckingham, Open University Press 2000.

[2] Kalache A, Lunenfeld B. Health and the ageing male. http://whqlibdoc.who.int/hq/2001/who_nmh_nph_0 1.2.pdf

[3] New South wales, health department. Moving forward in Men's health. www.health.nsw.gov.au 1999.
[4] Pasayat A. Sushil Kumar Sharma vs. union of India and Ors on 19 July, 2005.

[5] Felix DS, Robinson WD, Jarzynka KJ. The influence of divorce on men's health. Journal of Men's Health 2013;10(1):3-7.

[6] Douglas EM, Hines DA. The help seeking experiences of men who sustain intimate partner violence: an overlooked population and implications for practice. Journal of Family Violence 2011;26(6):473-85.

[7] http://www.liebertpub.com/global/pressrelease/ho w-does-divorce-affect-a-mans-health/1327/

[8] Banks I. No man's land: men, illness and the NHS British Medical Journal 2001;323(7320):1058-60.

[9] http://judis.nic.in/supremecourt/imgs1.aspx?filenam $\mathrm{e}=41767$.

[10] Connel RW. Gender and power: society, the person, and sexual politics. Stanford University Press 1987:p 334.

[11] http://www.worldlifeexpectancy.com/india-lifeexpectancy.

[12] Smith JA, Braunack-Mayer A, Wittert G. What do we know about men's health seeking and health service use? Med J Aust 2006;184(2):81-3.

[13] Courtenay WH. Construction of masculinity and their influence on men's well-being: a theory of gender and health. Social Sciences and Medicine 2000;50(10):1385-401.

[14] http://www.healthypeople.gov/2020/topicsobjective s2020/overview.aspx?topicid=39. 